\title{
Adhesion of Gardnerella vaginalis to vaginal epithelial cells: variables affecting adhesion and inhibition by metronidazole
}

\author{
M PEETERS AND P PIOT \\ From the Department of Microbiology, Institute of Tropical Medicine, Antwerp, Belgium
}

SUMMARY Variables affecting the adherence of Gardnerella vaginalis to human vaginal epithelial cells were examined in vitro. Adherence depended on $\mathrm{pH}$, with maximum attachment occurring between $\mathrm{pH} 5$ and $\mathrm{pH}$ 6. Preincubation of the bacteria at $56^{\circ} \mathrm{C}$ for 30 minutes and ultraviolet irradiation resulted in a noticeable decrease in adherence. In contrast, adherence was not altered by preincubating the epithelial cells under these conditions. Periodate oxidation of the vaginal cells caused an appreciable reduction in subsequent adherence of $G$ vaginalis. None of the 19 single carbohydrates tested inhibited adherence completely.

Metronidazole at subinhibitory concentrations for $G$ vaginalis, appreciably reduced the adhesive capacity of $G$ vaginalis, whereas subinhibitory concentrations of ampicillin did not.

\section{Introduction}

Gardnerella vaginalis and obligate vaginal anaerobes have been implicated in the pathogenesis of bacterial vaginosis (non-specific vaginitis), the main signs of which include an abnormal vaginal discharge, an increased vaginal $\mathrm{pH}(\mathrm{pH}>4 \cdot 5)$, the liberation of characteristic amines on alkalinisation of vaginal secretions, and the presence of "clue" cells in vaginal fluid. "Clue" cells are vaginal epithelial cells covered by large numbers of Gram negative to Gram variable coccobacilli. ${ }^{12}$

As is the case in several infections, adhesion of $G$ vaginalis to epithelial cells may be an important step in the pathogenesis of bacterial vaginosis. We evaluated variables influencing adhesion of $G$ vaginalis to exfoliated vaginal epithelial cells in vitro. The effect of exposure of $G$ vaginalis to subinhibitory concentrations of metronidazole and ampicillin on in vitro adherence was also studied.

Patient, materials, and methods

ORGANISMS AND CULTURE CONDITIONS

We used five strains of $G$ vaginalis throughout this

Address for reprints: Dr P Piot, Department of Microbiology, Institute of Tropical Medicine, Nationalestraat 155, B-2000 Antwerpen, Belgium

Accepted for publication 3 April 1985 study: strain NCTC 10287 (ATCC 10418), and four strains (2301-1, 68931, 68976, and 68977) isolated in our laboratory from patients with signs and symptoms of bacterial vaginosis. The organisms were stored as stock cultures at $-70^{\circ} \mathrm{C}$ in tryptic soy broth (Difco, Detroit, United States of America) with $50 \%$ donor horse serum (Gibco, Paisley, Scotland). Strains were cultured on Columbia agar (BBL, Cockeysville, USA) with $5 \%$ human blood at $35^{\circ} \mathrm{C}$ for 48 hours in an atmosphere containing $5 \%$ carbon dioxide. Subcultures were made in $2 \mathrm{ml}$ modified PMD broth (proteose peptone no 3 (Difco) $15 \mathrm{~g}$, maltose (Difco) $10 \mathrm{~g}$, dextrose (Difco) $2 \mathrm{~g}$, disodium hydrogen phosphate $0.008 \mathrm{~mol} / \mathrm{l}$ water $\left(1 \mathrm{~g} \mathrm{Na}_{2} \mathrm{HPO}_{4}\right.$ ) (Merck, Darmstadt, Germany) and sodium dihydrogen phosphate $0.007 \mathrm{~mol} / 1$ water $\left(1 \mathrm{~g} \mathrm{NaH} \mathrm{PO}_{4} 2 \mathrm{H}_{2} \mathrm{O}\right)$ (Merck) in $900 \mathrm{ml}$ water; supplemented with 20 g yeast extract (Difco) and $100 \mathrm{ml}$ fetal calf serum (Gibco)) incubated for 24 hours at $35^{\circ} \mathrm{C}$ in an atmosphere of $5 \%$ carbon dixoide.

Before performing the adherence assay, we washed the subcultures three times by centrifugation for 15 minutes at $800 \times g$ in phosphate buffered saline (PBS) pH 7.2 (Oxoid, London, England). The final pellet was resuspended in a volume of Mcllvaine's citrateacetate-phosphate buffer pH 5.5. This buffer consisted of two solutions: solution A contained citric acid $0.1 \mathrm{~mol} / 1$ water $\left(21 \mathrm{~g} \mathrm{C}_{6} \mathrm{H}_{8} \mathrm{O}_{7} 1 \mathrm{H}_{2} \mathrm{O}\right.$ in one litre of water), and solution $\mathrm{B}$ contained disodium hydrogen 
phosphate $0 \cdot 2 \mathrm{~mol} / \mathrm{l}$ water $\left(35 \cdot 6 \mathrm{~g} \mathrm{Na}_{2} \mathrm{HPO}_{4} 2 \mathrm{H}_{2} \mathrm{O}\right.$ in one litre of water). Both solutions had $9 \mathrm{~g}$ sodium chloride added.

\section{VAGINAL EPITHELIAL CELLS}

Throughout the study we used cells from the same donor, who used oral contraception but did not receive any antimicrobial treatment. We obtained the cells by gently scraping the vaginal mucosa with a sterile cotton swab, which was immediately immersed in PBS. The cell suspension was then washed three times by centrifugation for 10 minutes at $150 \times g$ in PBS to remove all vaginal bacterial flora. Finally we resuspended the cells in McIlvaine's buffer pH 5.5, and counted them in a Neubauer counting chamber.

\section{ADHERENCE ASSAY}

We measured bacterial adherence by a modification of the methods of several workers. ${ }^{3-6}$ Samples of $1 \mathrm{ml}$ of standard bacterial suspensions $\left(2 \cdot 1 \times 10^{8}\right.$ bacteria $\left./ \mathrm{ml}\right)$ were mixed with equal volumes of vaginal cell suspensions $\left(10^{5}\right.$ cells $\left./ \mathrm{ml}\right)$ in small, flat bottomed tubes. The ratio of bacteria to vaginal cells was based on preliminary experiments, which had shown that the enumeration of adherent bacteria was most reproducible at a ratio of $10^{8}: 10^{5}$. The tubes were rotated at $35 \mathrm{rpm}$ at $37^{\circ} \mathrm{C}$ for 45 minutes in a shaking waterbath.

After the epithelial cells had been incubated, they were washed free of non-adherent bacteria by filtration through a $12 \mu \mathrm{m}$ polyester filter (Nucleopore) held in a millipore filter holder mounted on the end of a syringe. Each filter was washed with 30 ml PBS. To transfer the cells to slides, the filter was carefully removed from the filter holder and inverted into a drop of PBS on a clean microscope slide. The filters were lifted off the slide after about two minutes. The slides were air dried, fixed in methanol for five minutes, and Gram stained. The number of bacteria adherent to epithelial cells was counted under a light microscope with a $\times 1000$ objective. In each experiment 50 epithelial cells were counted. All experiments were performed at least twice.

\section{VARIABLES INFLUENCING THE ADHERENCE OF G VAGINALIS}

We studied the effect of $\mathrm{pH}$ by resuspending the strains of $G$ vaginalis and the vaginal epithelial cells in a McIlvaine's citrate-acetate-phosphate buffer at a pH range of $\mathrm{pH} 3$ to $\mathrm{pH} 8$.

Pretreatment of vaginal cells included incubating the cell suspension at $56^{\circ} \mathrm{C}$ for 30 minutes and ultraviolet irradiation by exposing the cell suspension in an open Petri dish to an ultraviolet lamp for $\mathbf{3 0}$ minutes. The distance between the lamp and the surface of the cell suspension was $10 \mathrm{~cm}$, and the irradiation at the surface was $1800 \mu \mathrm{W} / \mathrm{cm}^{2}$. Cell suspensions were also treated with $10 \mathrm{mg} / 1$ sodium-meta-periodate (Merck) for five minutes at room temperature in $5 \mathrm{ml}$ PBS. The cells were then washed twice in PBS before being resuspended in McIlvaine's buffer to the required concentration.

Pretreatment of bacteria consisted of temperature, ultraviolet, and periodate treatments as described for the epithelial cells. Pretreatment of bacteria with various sugars was by incubating washed bacteria with the respective carbohydrates at concentrations of $0 \cdot 1$ or $0.2 \mathrm{~mol} / 1$ PBS. Bacteria were washed before the adherence assay was performed.

We tested the effect of antibiotics on adhesion as follows. We measured minimum inhibitory concentrations (MIC) of metronidazole (Specia NV, Brussels) and ampicillin (Beecham, Brussels) for each bacterial strain by using a macrobroth dilution method. Serial dilutions of either compound were prepared in $2 \mathrm{ml}$ PMB broth supplemented with $2 \%$ yeast extract and $10 \%$ fetal calf serum. The tubes were inoculated with $10^{6}$ bacteria/ml and incubated for 24 hours at $35^{\circ} \mathrm{C}$ in an atmosphere of $5 \%$ carbon dioxide. The MIC was defined as the lowest concentration of antibiotic that inhibited visible bacterial growth. We performed adherence assays with strains of $G$ vaginalis grown in the presence of metronidazole or ampicillin at concentrations corresponding to one half, one quarter, or one eighth of the MIC of each antimicrobial.

All experiments included a control, which consisted of an adherence assay of untreated epithelial cells and bacteria performed at the same time.

\section{STATISTICAL METHODS}

We obtained the variation of the distribution by calculating the standard error of the mean. The significance of differences between means was analysed using the Kruskal-Wallis test, as the data were not normally distributed and a transformation did not bring the differences between the variances to an acceptable level. ${ }^{7}$

\section{Results}

INFLUENCE OF pH ON ADHERENCE

Adherence of $G$ vaginalis was maximum at pH 5 to 6 and declined at $\mathrm{pH}$ values below and above this range (fig 1). Based on these results, we performed all adherence studies at pH $5 \cdot 5$. The number of adherent bacteria at these conditions varied between 8.4 and $17 \cdot 4 /$ cell.

PRETREATMENT OF BACTERIA AND EPITHELIAL CELLS

Pretreatment of $G$ vaginalis with mild heat and ultraviolet irradiation caused a significant $(p<0.005)$ drop in the attachment of the organism to the vaginal 


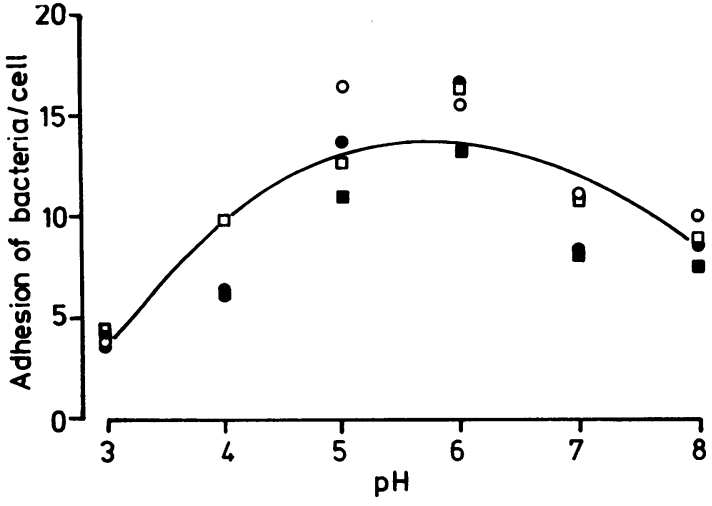

FIG 1 Influence of $\mathrm{pH}$ on adhesion of four strains of Gardnerella vaginalis $(\bullet=$ strain $68631, \bullet=$ strain 68976 , $\square=$ strain 68977, $0=$ strain NTCC 10287) to vaginal epithelial cells. Values shown are means obtained from two experiments. The best curve was fitted through these values with a correlation coefficient of $0 \cdot 76$. glucopyranoside, $\mathrm{N}$-acetyl-glucosamine, and xylose had no influence on adherence of the bacteria to the vaginal cells. All other sugars tested reduced the attachment rate, but none inhibited adhesion completely (table III). Noticeable and consistent differences were observed between the different strains tested.

EFFECT OF SUBINHIBITORY CONCENTRATIONS OF METRONIDAZOLE AND AMPICILLIN

MICs of metronidazole and ampicillin were $16 \mathrm{mg} / \mathrm{l}$ and $0.015 \mathrm{mg} / \mathrm{l}$ for strain $2301-1,16 \mathrm{mg} / \mathrm{l}$ and 0.031 $\mathrm{mg} / \mathrm{l}$ for strains 6893 and 68977 , and $4 \mathrm{mg} / \mathrm{l}$ and 0.015 $\mathrm{mg} / \mathrm{l}$ for strain 68976 . $G$ vaginalis strains grown in the presence of metronidazole exhibited a greatly altered capacity for adhesion. Thus metronidazole at subinhibitory concentrations caused a noticeable reduction in the adhesion of strains 2301-1, 68976, and 68977 , but did not influence the adhesion of strain 68931 to vaginal epithelial cells (fig 2). In contrast,

TABLE I Effect of pretreatment of Gardnerella vaginalis on its adherence to vaginal epithelial cells

\begin{tabular}{|c|c|c|c|c|c|c|}
\hline \multirow[b]{2}{*}{ Treatment } & \multicolumn{5}{|c|}{ Mean* (SEM) adherence of strain: } & \multirow[b]{2}{*}{$p$ value } \\
\hline & $2301-1$ & 68931 & 68976 & 68977 & NTCC10287 & \\
\hline $\begin{array}{l}\text { Heat }\left(30 \mathrm{~min} \text { at } 56^{\circ} \mathrm{C}\right) \\
\text { Ultraviolet irradiation } \\
\text { Sodium-meta-periodate }\end{array}$ & $\begin{array}{l}17(4) \\
28 \quad(5) \\
61(13)\end{array}$ & $\begin{array}{l}24(5) \\
23(10) \\
97(24)\end{array}$ & $\begin{array}{l}28(7) \\
16(4) \\
64(11)\end{array}$ & $\begin{array}{ll}31 & (7) \\
27 & (7) \\
84 & (22)\end{array}$ & $\begin{array}{r}44(9) \\
23(10) \\
153(19)\end{array}$ & $\begin{array}{l}<0.005 \\
<0.005 \\
<0.01\end{array}$ \\
\hline
\end{tabular}

* Mean bacteria/cell as percentage of untreated control.

$\ddagger$ Kruskall-Wallis test.

TABLE II Effect of pretreatment of vaginal epithelial cells on adherence of Gardnerella vaginalis

\begin{tabular}{lllllr}
\hline & \multicolumn{5}{l}{ Mean* (SEM) adherence of strain: } \\
\cline { 2 - 6 } Treatment & $2301-1$ & 68931 & 68976 & 68977 & NTCC10287 \\
\hline Heat $\left(30\right.$ min at $\left.56^{\circ} \mathrm{C}\right)$ & $59(21)$ & $31(14)$ & $135(28)$ & $78(17)$ & $91(1)$ \\
Ultraviolet irradiation & $50(18)$ & $99(18)$ & $81(16)$ & $32(9)$ & $103(14)$ \\
Sodium-meta-periodate & $22(5)$ & $27(7)$ & $32(6)$ & $27(8)$ & $33(8)$ \\
\hline
\end{tabular}

* Mean bacteria/cell as percentage of untreated control.

$\ddagger \mathrm{p}<0.005$, Kruskall-Wallis test.

cells (table I). Periodate treatment of the bacteria significantly $(p<0.01)$ reduced the adhesion, but to a lower extent than when the epithelial cells underwent periodate pretreatment $(p<0.005)$. Moreover, only two bacterial strains out of five tested showed a pronounced decrease in adhesion after periodate treatment (table II). Mild heat treatment, for 30 minutes at $56^{\circ} \mathrm{C}$, and ultraviolet irradiation of the epithelial cells caused no significant decrease in the attachment of $G$ vaginalis to the vaginal cells.

PRETREATMENT WITH VARIOUS SUGARS

Of all the sugars tested, arabinose, cellobiose, fructose, galactose, mannose, melibiose, $\alpha$-methyl-
TABLE III Effect of pretreatment of Gardnerella vaginalis with selected sugars on adherence to vaginal epithelial cells

\begin{tabular}{llllll}
\hline & \multicolumn{4}{c}{ Mean* (SEM) attachment of strain: } \\
\cline { 2 - 6 } Carbohydrate & $2301-1$ & 68931 & 68976 & 68977 & NTCC10287 \\
\hline Fucose & $71(15)$ & $61(14)$ & $78(17)$ & $58(11)$ & $102(17)$ \\
Glucose & $27(7)$ & $42(9)$ & $38(9)$ & $43(14)$ & $61(12)$ \\
Glycogen & $84(25)$ & $35(15)$ & $26(12)$ & $26(8)$ & $42(12)$ \\
Maltose & $40(8)$ & $45(9)$ & $56(12)$ & $54(15)$ & $80(13)$ \\
Mannitol & $74(23)$ & $84(24)$ & $53(12)$ & $67(19)$ & $49(10)$ \\
N-acetyl- & & & & & \\
galactosamine & $25(7)$ & $92(22)$ & $54(12)$ & $55(9)$ & $61(9)$ \\
Raffinose & $58(16)$ & $52(12)$ & $61(13)$ & $48(15)$ & NT (3) \\
Sucrose & $34(11)$ & $78(19)$ & $46(8)$ & $61(15)$ & $70(10)$ \\
Starch & $49(20)$ & $43(16)$ & $25(10)$ & $33(11)$ & $77(15)$ \\
\hline
\end{tabular}

* Mean bacteria/cell as percentage of untreated control. $\mathrm{NT}=$ Not tested. 


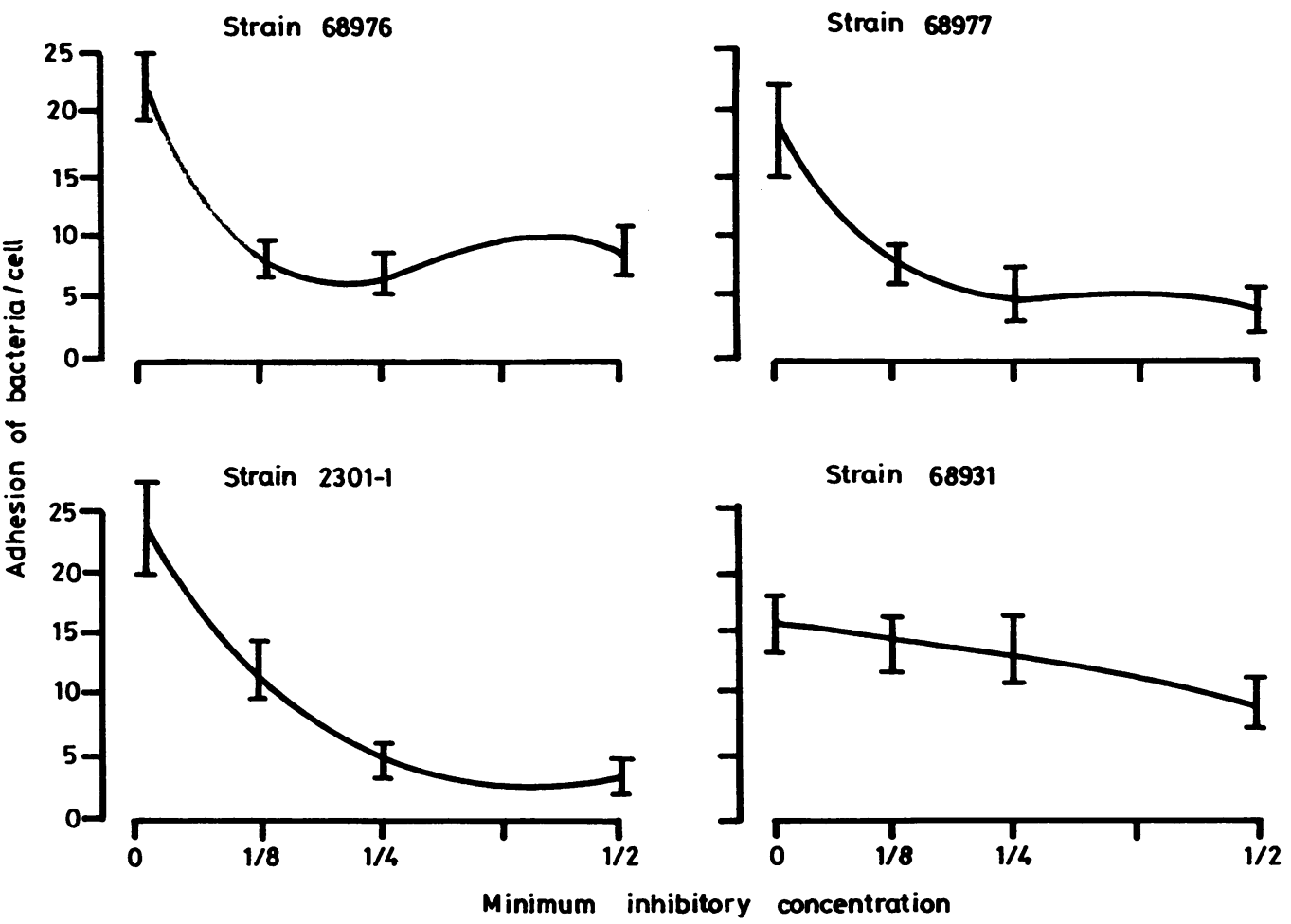

FIG 2 Influence of subinhibitory concentrations of metronidazole on the adherence of four strains of Gardnerella vaginalis to vaginal epithelial cells. Values shown are means (bars SEM) obtained from two experiments. The best curves were fitted through these values with correlation coefficients of: 0.95 (strain 2301-1), 0.98 (strain 68931), 0.99 (strain 68976), and 0.97 (strain 68977).

ampicillin at subinhibitory concentrations did not alter the capacity of adhesion of the four strains of $G$ vaginalis (data not shown).

\section{Discussion}

The study reported here confirms that $G$ vaginalis has a good capacity to adhere to vaginal epithelial cells in an experimental model. ${ }^{68}$ The optimum $\mathrm{pH}$ for adhesion in vitro was pH 5 to 6 (the vaginal pH of women with bacterial vaginosis), and adhesion was limited at $\mathrm{pH} 3$ to 4 (the pH of vaginal fluid in women without vaginosis). If the same is true in vivo, $a$ rise in vaginal $\mathrm{pH}^{-}$is possibly a prerequisite in the pathogenesis of bacterial vaginosis and perhaps precedes the formation of the pathognomonic "clue" cells, which are vaginal epithelial cells covered with $G$ vaginalis.

Mild heat treatment and ultraviolet irradiation of the vaginal epithelial cells did not alter the degree of attachment. Treatment with sodium-meta-periodate, which destroys the $\mathrm{C}-\mathrm{C}$ bond between vicinal hydroxyl groups of carbohydrates, caused an appreciable drop in the number of bacteria attached to the cells. This suggests that a carbohydrate on the surface of the epithelial cells plays a part in the binding mechanism. We were unable to identify this carbohydrate, however, as attachment to the vaginal cells was not completely inhibited by a single monosaccharide tested. Adherence studies in the presence of the hapten sugars may yield more. A disaccharide, trisaccharide, or larger unit is possibly concerned, and distinct linkages are perhaps necessary to serve as a receptor molecule. ${ }^{59-13}$

On the other hand, mild heat, ultraviolet irradiation, and periodate treatment of the bacteria reduced the degree of attachment. This suggests that a protein, and perhaps a carbohydrate as well, is important for adhesion. This is in contrast with the findings with other bacteria by most workers, in which only a protein was implicated in the function of an adhesin. ${ }^{512}$

Subinhibitory concentrations of various antibiotics have recently been shown to interfere with the capacity of bacteria to adhere to cells. ${ }^{14}$ is Attachment of $G$ vaginalis to vaginal epithelial cells was not influenced by growth of the organism in the presence of subinhibitory concentrations of ampicillin. This contrasts with the influence of ampicillin on the 
adhesion of streptococci to buccal epithelial cells, ${ }^{12}$ which suggests that streptococci and $G$ vaginalis use different adhesion mechanisms or receptors. Subinhibitory concentrations of metronidazole did appreciably reduce the adhesion of $G$ vaginalis to vaginal epithelial cells, with a noticeable drop in adherence starting at a concentration equalling one eighth of the MIC of metronidazole. The data also suggest, however, that this may not be the case for all strains of $G$ vaginalis, as shown by the results for strain 68931. The mechanism of activity of metronidazole for the treatment of bacterial vaginosis has been a controversial issue. ${ }^{16-19}$ Whereas metronidazole has excellent in vitro activity against the anaerobes associated with bacterial vaginosis, it is only moderately active against $G$ vaginalis, with MICs ranging between $4 \mathrm{mg} / \mathrm{l}$ and $32 \mathrm{mg} / 1.2021$ Our data suggest that part of the activity of metronidazole in bacterial vaginosis is possibly due to a reduction of attachment of $G$ vaginalis to epithelial cells. This attachment in itself may be a cause of epithelial cell lysis, and play a part in the pathogenesis of bacterial vaginosis.

Further studies are required to define better the role of adherence of $G$ vaginalis to epithelial cells in the pathogenesis of bacterial vaginosis, and to identify both receptors and adhesins concerned in attachment.

\section{References}

1. Lossick JG. Gardnerella vaginalis - associated leukorrhea. The disease and its treatment. Rev Infect Dis 1982;4 suppl:793-800.

2. Gardner HL, Dukes CD. Haemophilus vaginalis vaginitis: a newly defined specific infection previously classified "nonspecific" vaginitis. Am J Obst Gynecol 1955;69-962-76.

3. Ellen RP, Gibbons RJ. Parameters affecting the adherence and tissue tropisms of Streptococcus pyogenes. Infect Immun 1974;9-85-91.

4. Zawaneh SM, Ayoub EM, Baer H, Cruz AC, Spellacy WN. Factors influencing adherence of group B streptococci to human vaginal epithelial cells. Infect Immun 1979;26e441-7.
5. Bagg J, Poxton IR, Weir DM, Ross PW. Binding of type-III group-B streptococci to buccal epithelial cells. JMed Microbiol 1982;15:363-72.

6. Mårdh, P-A, Westrom L. Adherence of bacteria to vaginal epithelial cells. Infect Immun 1976;13:661-6.

7. Sokal RR, Rohlf FJ. Biometry. San Francisco: Freeman and Company, 1981.

8. Sobel JD, Schneider J, Kay D, Levison ME. Adherence of bacteria to vaginal epithelial cells at various times in the menstrual cycle. Infect Immun 1981;32:1947.

9. Ramphal R, Pyle M. Evidence for mucins and sialic acid as receptors for Pseudomonas aeruginosa in the lower respiratory tract. Infect Immun 1983;41:339-44.

10. Trust TJ, Gillespie RM, Bhatti AR, White LA. Differences in the adhesive properties of Neisseria meningitidis for human buccal epithelial cells and erythrocytes. Infect Immun 1983;41:106-13.

11. Andersson B, Leffler H, Magnusson G. Edén CS. Molecular mechanisms of adhesion of Streptococcus pneumoniae to human oropharyngeal epithelial cells. Scand J Infect Dis [Suppl] 1983;39:45-7.

12. Beachey EH. Bacterial adherence: adhesin-receptor interactions mediating the attachment of bacteria to mucosal surfaces. J Infect Dis 1981;143:325-45.

13. Abraham SN, Beachey EH, Simpson WA. Adherence of Streptococcus pyogenes, Escherichia coli, and Pseudomonas aeruginosa to fibronectin-coated and uncoated epithelial cells. Infect Immun 1983;41:1261-8.

14. Vosbeck K. Mett H, Huber U, Bohn J, Petignat M. Effects of low concentrations of antibiotics on Escherichia coli adhesion. Antimicrob Agents Chemother 1982;21:8649.

15. Lorian $\mathbf{V}$. Effects of subminimum inhibitory concentrations of antibiotics on bacteria. In: Lorian V, ed. Antibiotics in laboratory medicine. Baltimore: Williams \& Wilkins, 1980:342408.

16. Pheifer TA, Forsyth PS, Durfee MA, Pollock HM, Holmes KK Nonspecific vaginitis: role of Haemophilus vaginalis and treatment with metronidazole. NEngl JMed 1978;298:1429-34.

17. Malouf M, Fortier M, Morin G, Dube J. Treatment of Haemophilus vaginalis vaginitis. Obstet Gynecol 1981;57:7114.

18. Baldson MJ, Pead L, Taylor GE, Maskell R. Corynebacterium vaginale and vaginitis: a controlled trial of treatment. Lancet 1980;i:501-3.

19. Piot $P$. Bacterial vaginosis: an evaluation of treatment. In Mărdh P-A, Taylor-Robinson D, eds. Bacterial vaginosis. Stockholm: Almqvist \& Wiksell International, 1984:229-35.

20. Ralph ED, Amatnicks YE. Relative susceptibilities of Gardnerella vaginalis (Haemophilus vaginalis), Neisseria gonorrhoeae and Bacteroides fragilis to metronidazole and its two major metabolites. Sex Transm Dis 1980;7:157-60.

21. Ralph ED, Austin TW, Pattison FLM, Schieven BC. Inhibition of Haemophilus vaginalis (Corynebacterium vaginale) by metronidazole, tetracycline and ampicillin. Sex Transm Dis 1979;6:199-202. 